\title{
Effect of Parental Musical Interest Background on Their Children's Choice of Music as a Course of Study
}

\author{
Grace E. Ekong (Ph. D) \\ Department Of Music University Of Uyo, Uyo, Akwa Ibom State, Nigeria
}

\begin{abstract}
This study examined the influence of parental musical interest; and academic background on children's interest in music as a course of study. Two research questions and two hypotheses were raised to guide the study. The study used ex-post facto research design. The study sample comprised 390 Basic 9 Music students selected from the 12 public secondary schools in Uyo Local Government offering music using simple random sampling technique. Researcher-developed instrument titled: Parental Musical Interest, Background and Children Musical Interest Questionnaire (PMIBCMIQ), a 22-item opinion scale with four response options was used for data collection. The instrument had a reliability index of .84 determined using Cronbach's alpha reliability coefficient formula. The results of data analysis using the independent t-test statistics showed that students whose parents are highly interested in music tend to be highly interested in musical studies too. Based on the findings, it was recommended, among others, that parents should properly guide their wards in their choice of career rather than dissuade them from their career of interest or try to force them into careers that they are not interested in.
\end{abstract}

Keywords: Children's interest in music; Parental academic background;;Parental musical interest; musical study

\section{Background}

Humanity refers to the human (man and woman) creature made in the likeness of the Supreme Being. Endowed with qualities and attributes unknown to him to develop, utilize, and create impact on his immediate and outer environment, this being, created with unrestricted freedom and liberty to choose between options, may like, love, hate, approve/disapprove, counter, condemn in totality what his nature beams the light. He tends to prefer certain things to some others. When he chooses a life partner, his likes/dislikes are religiously nurtured or condemned, though at times with severe reprimand. This transcends into their first important close associates, their offspring.

Psychologists have made several attempts at laying bare to us certain conditions/changes which take place in man and his reactions, positive or negative. They have made us to understand that humans possess some traits which are innate (probably acquired hereditarily) or born out of influences from relations/interactions/experiences with the outer society. Musical traits stand out as one of such traits which could be acquired hereditarily, that is, springing from a child's parental musical interest/inclinations. A child is born with it and may, in the course of his growth, development, and exposure, exhibit this trait, or may deliberately ignore it. To Sloboda, Davidson, and Howe (2009: 48),

Folk psychology assumes that differences between people in musical ability are directly caused by inherent biological variability. From birth, some individuals are supposed to have an inborn potential to be musical, or have a natural talent or gift for music, or innate aptitude for it.

Ignoring the musical trait may depend on a child's sense of valuing. He has several options, like his parents, to choose from. He may naturally prefer what his parents prefer or value. He may, in the same vein, shun his parents' favourites. Barnett and Chick, Kelly, Kleiber, Hutchinson, Baldwin and Cladwell, all cited in Ho (2011), assert that parents are significant factors in the development of children's leisure interests and values.

Abeles, Hoffer, and Klotman (1976) see music as a form of human behaviour created by human beings for human beings. This musical behaviour, according to them, is bound to be influenced by certain factors, namely, biological, social, cultural, and technological factors. Biological factors tend to relate with the make up of the human and his intrinsic qualities. Humans have the tendency to follow or accept what others do or think and this conformist behaviour can be strong enough to affect musical interests (Abeles et al). It is only when there is a sense of valuing and appreciation of attributes that conformity is likely to take effect. Interest, valuing and appreciation, according to Tyler (1986) are sub-categories of the affective objectives of education. To Tyler, valuing is an emotional commitment, to those cherished objects, activities or ideas which drive or direct the interests, attitudes, and satisfactions of individuals cherishing the objects, activities or ideas. Interest refers to a feeling of curiosity or concern about something that makes the attention turn towards it; or a power, quality or aspect of something that attracts attention, concern or curiosity (Microsoft Encarta, 2009). 
These definitions imply that there must be an appreciation of the object or thing which the individual derives joy and satisfaction from. Tyler (1986) opines that one desires more of the thing he/she appreciates; desires to express himself/herself creatively; and identifies himself/herself with the object appreciated. In the light of this, children may tend to appreciate and identify themselves with what their parents hold in high esteem and are inclined to. In a study conducted by Ho (2011), the findings revealed that $47.4 \%$ of respondents (students) perceived their parents as the most influential people for their learning instruments, $26 \%$ rated private instrumental tutor; $7.6 \%$ rated school music teacher; $7.3 \%$ - friends/classmates; $3.5 \%$ - brothers and sisters; $3.5 \%$ - orchestra conductor; while $3.0 \%$ rated orchestra member and others $-1.8 \%$. In the same study, 14-rank reasons for learning music instruments were stated by Ho for respondents' rating. Students' interest (48.4\%) was rated highest followed by parental encouragement $(18.8 \%)$. The study also revealed that these parents learned musical instruments. Though the study was based on the learning of musical instruments, it has implication for general classroom music studies.

\section{The Problem}

Music education is seen as a weapon for combating ignorance, poverty, and disease; a bridge between confusion and comprehension, a dam for conserving man's stores of civilisation, a rocket subservient to a state of intellectual sovereignty, and an instrument par excellence for effective national development ( Amoyedi cited in Essien, 2011). These, therefore, place a great demand and responsibility on not only music educators, but everyone inhabiting a geographical entity including parents. Parents prepare the grounds for teachers while governments provide the enabling environment/tools for these ideals to be achieved. The level of preparations and provisions of ideal environments/tools, in this regard, determine whether these ideals will flourish or remain moribund. With the high emphasis on science and technology and low intake of students into music departments of Universities across the nation, opinion of some people points to the fact that academic music study may lose its pride of place in the scheme of things. Besides, most families are not giving their children/wards the needed encouragement and support even when musical traits are glaring in them. RusselBowie, Mclnerney, and Yeung (2001) assert that many families fail to provide children with nurturing musical background. The home, they opine, is the bedrock of every child's developmental prospect. Several studies have shown that the home constitutes the most influential factor on student learning (Garber \& Ware, 1972; Shapiro \& Bloom, 1977; Revicki, 1981; Kalinowski \& Sloane, 1981; Olson, 1984; Brand, 1986; Asmus, 1986; Olszewski, Kulieke, \& Buescher, 1987; Kemp, 1996; Shiraishi, 1997; Cleveland, Jacobson, Lipinski, \& Rowe, 2000). Kemp (1996) sees the home environment as the key element in the development of musical talent, particularly in the early stages of development. In the same vein, Olszewski, Kulieke, and Buescher (1987) opine that parents often have the power to direct their children away or toward certain activities, particularly when their children are young. Parents' interest and involvement in their children's/wards' musical training determine whether the children/wards will continue with music lessons and practice ( Creech \& Hallam; Moore, Burland, \& Davidson; cited in Ho, 2011). It is most likely that parental musical interest background may be the strongest predictor of their children's interest in music as a course of study.

This researcher had witnessed many situations where students, having been admitted into and enrolled in the department to study music, had opted out for other courses. One of the major reasons for such withdrawals had been parental factors (Parents' dislike for music as an academic discipline in schools). Such parents see music as a course not worth studying in school.

There is need, therefore, to ascertain the root cause of this malady. Could the cause be attributed to the children's musical background? Could parental musical interest background affect their children's/wards' interest in academic music pursuit? Could students' interest in academic music study be a function of the academic background of the parents? This paper, therefore, set out to examine the influence of parental musical interest background as a factor in children's interest in music as a course of study.

\section{Purpose of the Study}

This study examined the influence of parental musical interest and academic background on children's interest in music as a course of study. The objectives were:

1. To determine the influence of parents' musical interest on their children's interest in musical study.

2. To examine the influence of parents' musical interest on their children's interest in musical study given their academic background.

\section{Research Questions}

In order to give this study a focus, the following research questions were posed:

1. How does parents' musical interest influence their children's interest in musical study? 
2. How does parents' musical interest influence their children's interest in musical study given their academic background?

\section{Hypotheses}

The following hypotheses were formulated and tested at .05 level of significance.

1. There is no significant influence of parental musical background on children's interest in music study.

2. There is no significant influence of parental academic background on children's interest in music study.

\section{Design}

\section{Methodology}

The study used ex-post facto research design. This design was chosen since both the independent and dependent variables had already occurred and the researcher only had to make inference based on the facts already on ground.

\section{Population}

The target population consisted of all the 5471Junior Secondary three (Basic 9) students in the 12 public schools in Uyo Local Government Area of Akwa Ibom State, Nigeria, where music is taught.

\section{Sample and Sampling Technique}

The study sample comprised 390 Basic 9 Music students selected from the 12 public secondary schools in Uyo Local Government offering music using simple random sampling technique.

\section{Instrumentation}

Researcher-developed instrument titled: Parental Musical Interest Background and Children Musical Interest Questionnaire (PMIBCMIQ), a 22 -item Likert scale with four response options was used for data collection. The options were Strongly Agree (4), Agree (3), Disagree (2), and Strongly Disagree (1). Four music experts validated the instrument. The final copy of the instrument was drawn after the experts' scrutiny and suggestions. The reliability index of the instrument, determined using Cronbach's Alpha yielded a reliability index of .84 .

\section{Method of Data Collection}

The researcher, with the assistance of the Music teachers in the selected schools, administered the questionnaire to the respondents during their normal Music periods. The completed copies of the questionnaire were collected on the spot, immediately after completion. This was necessary to forestall non-return of the questionnaire.

\section{Method of Data Analysis}

Data generated from the study were analysed using the independent t-test statistics.

\section{Results}

Research Hypothesis One: There is no significant influence of parental musical background on children's interest in music study.

Table 1: Independent t-test Analysis of Scores on Parents' Musical Interest and Children's Interest in Musical Study $(\mathrm{n}=390)$

\begin{tabular}{lccccccc}
\hline Parents' Musical Interest & $\mathrm{N}$ & Mean & $\begin{array}{c}\text { Std. } \\
\text { Deviation }\end{array}$ & t cal & Df & Sig. & Decision \\
\hline High & 266 & 28.38 & 2.08 & 1.54 & 388 & 0.02 & $\mathrm{~S}$ \\
Low & 124 & 26.14 & 2.68 & & & & \\
\hline
\end{tabular}

In Table 1, the results show that the calculated $t$ value, $t$-cal, for parents' musical interest and their children's interest in musical study is 1.54 at df 388 , and that the calculated level of confidence, Sig., is 0.02 . This probability level is less than 0.05 in which decision is based indicating that there is a significant influence of parents' musical interest on their children's interest in musical study. Hence, hypothesis 1- There is no significant influence of parental musical background on children's interest in music study - was rejected. The mean scores of 28.38 for those whose parents are highly interested in music and 26.14 for those whose parents are not interested in music in Table 1indicates that students whose parents are highly interested in music tend to be highly interested in musical studies.

Research Hypothesis Two: There is no significant influence of parental academic background on children's 
interest in music study.

Table 2: Independent t-test Analysis of Scores on Parental Academic Background and Children's Interest in Musical Study $(\mathrm{n}=390)$

\begin{tabular}{lccccccc}
\hline Parental Academic Background & $\mathrm{N}$ & Mean & $\begin{array}{c}\text { Std. } \\
\text { Deviation }\end{array}$ & t cal & Df & Sig. & Decision \\
\hline High & 279 & 26.38 & 2.08 & 2.82 & 388 & 0.12 & NS \\
Low & 111 & 26.14 & 2.33 & & & & \\
\hline
\end{tabular}

In Table 2, the results show that the calculated $t$ value, $t-c a l$, for parents' musical interest and their children's interest in musical study is 2.82 at df 388 , and that the calculated level of confidence, Sig., is 0.12 . This probability level is greater than 0.05 in which decision is based. This indicates that there is no significant influence of parental academic background on their children's interest in musical study. Hence, hypothesis 1There is no significant influence of parental musical background on children's interest in music study - was upheld.

\section{Discussion}

This study examined the influence of parental musical interest and academic background on children's interest in music as a course of study. The results in Tables 1 and 2 indicated that there is a significant influence of parents' musical interest on their children's interest in musical study and that there is no significant influence of parental academic background on children's interest in musical study. Students whose parents are highly interested in music tend to be highly interested in musical studies too. This is in tandem with Ho's (2011) findings that parents who are interested in music would support their children's interest in musical study. The no significant influence of parental academic background on their children's interest in musical study implies that parental academic background is not a significant predictor of children's interest in musical study.

\section{Conclusion}

Consequent upon the findings of this study, it is hereby concluded that parents' musical interest is a significant predictor of children's interest in musical study but parental academic background is not.

\section{Recommendations}

Based on the observations made, it is recommended that parents should properly guide their wards in their choice of career rather than dissuade them from their career of interest or try to force them into careers that they are not interested in. It is also recommended that this study should be replicated in other parts of the country to allow for effective generalization of findings.

\section{References}

[1]. Abeles, H. F., Hoffer, C. R., \& Klotman, R. H. (1979). Foundations of music education. New York: Schirmer Books.

[2]. Asmus, E. P. (1985). Students' beliefs about the causes of success and failure in music: A study of achievement motivation. Journal of Research in Music Education, 34, 262 - 278.

[3]. Brand, M. !986). Relationship between home musical environment and selected musical attributes of second-grade children. Journal of Research in Music Education, 34, 112 -120.

[4]. Cleveland, H. H., Jacobson, K.C., Lipinski, J. J., \& Rowe, D. C. (2000). Genetic and shared environmental contributions to the relationship between the home environment and child and adolescent achievement. Intelligence, 28(1), 6986.

[5]. Essien, M. A. (2011). Indigenous instructional materials in the music education of secondary schools in Akwa Ibom State. Journal of the Association of Nigerian Musicologists (JANIM), (5), $130-140$.

[6]. Garber, M., \& Ware, W. B. (1972). The home environment as a predictor of school achievement. Theory into Practice, 11(3), 190 -195 .

[7]. Ho, W. C. (2011). Parental support and student learning of musical instruments in Hong Kong. Visions of Research in Music Education, 19. Retrieved from http://www-usr.rider.edu/vrme-/

[8]. Kalinowski, A., \& Sloane, K. (1981). The home environment and school achievement. Studies in Educational Evaluation, 7(1), 85 $-96$.

[9]. Kemp, A. E. (1996). The musical temperament. Oxford: Oxford University Press.

[10]. Olson, C. C. (1984). Effects of parenting and home environment on student achievement in grades 3 to 5 . A paper presented at the Annual Meeting of The American Educational Research Association (68 ${ }^{\text {th }}$ ), New Orleans, L. A., April 23 -27, 1984). (ERIC Document Reproduction Service No. ED 247002).

[11]. Olsewski, P., Kulieke, M., \& Buescher, T. (1987). The influence of the family environment on the development of talent: A literature review. Journal for the Education of the Gifted, 11, (1), 6-28.

[12]. Revicki, D. A. (1981). The relationship among socioeconomic status, home environment, parent involvement, child self-concept, and child achievement. ERIC Document Reproduction Service No. ED206645.

[13]. Shapiro, C., \& Bloom, J. S. (1977). Home environment, self-concept, and urban students achievement: A bibliography and review of research. Trenton, N. J.:

[14]. New Jersey State Department of Education. (ERIC Document Reproduction Service No. ED161972).

[15]. Shiraishi, I. M. (1997). A home-based music therapy program for multi-risk mothers. Music Therapy Perspectives, $15(1), 16-23$. 
[16]. Tyler, R. W. (1986). Changing concepts of educational evaluation. International Journal of Educational Research, $10(4), 94-101$.

\section{Internet Sources}

[17]. Asmus, E. P. (2009). The impact of music education on home, school, and community.

[18]. http://www.uncg.edu/mus/SoundsOfLearning/HomeSchoolCommunity.pdf [Accessed June 24, 2009 ].

[19]. Encarta Dictionary On-line (2009). Interest. http://encarta.msn.com/dictionary/Interest.html [Accessed June 8, 2009].

[20]. Russell-Bowie, D., Mclnerney, D. M., \& Yeung, A. (2001). Student teachers' perceptions of anxiety and confidence in relation to music education. $<$ http://www.aare.edu.au/01 pap/rus01123.htm $>$ [Accessed June 8, 2009].

\section{Parental Musical Interest Background And Children Musical Interest Questionnaire (Pmibcmiq),}

\section{Section A: Parental Musical/Academic Background}

1. Gender: Male $\square$ Female

2. Which of your parents is very much interested in music?

Father $\square$ Mother $\square$ None

3. Is any of your parents a musician? Yes $\square$ No

4. If Yes, Which? Father $\square$ Mother $\square$ None

5. What is the highest educational qualification of:

a. Your mother?

FSLC

B. A/B.Sc/B.Ed

WASC or Equivalent

M.A/M.Sc/M.Ed. and Above

N.C.E.

b. Your father?

FSLC $\square$ WASC or Equivalent $\square$ N.C.E.

B. A/B.Sc/B.Ed. $\square$ M.A/M.Sc/M.Ed. and Above

6. Which of your parents studied music in school?

Father $\square$ Mother $\square$ None

Section B: Parents’ Musical Interest Background

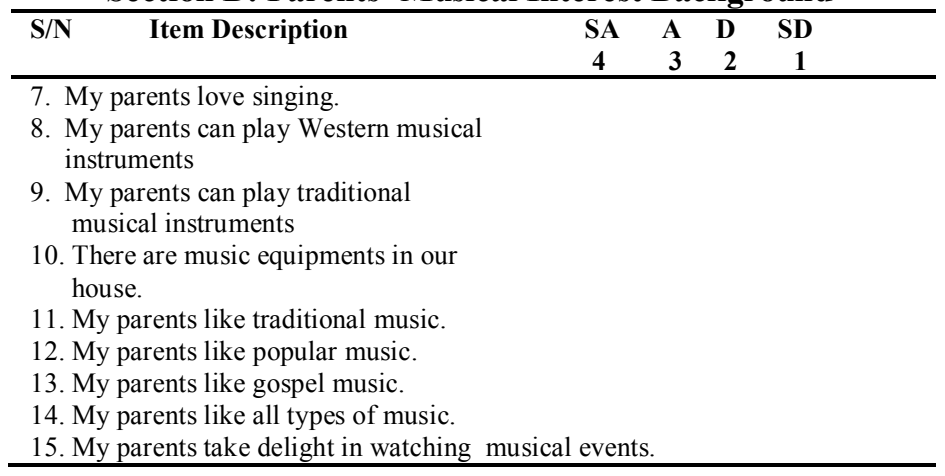

Section C: Students' Interest In Music As A Course Of Study

\begin{tabular}{lrrrr}
\hline S/N Item Description & SA & A & D & SD \\
& $\mathbf{4}$ & $\mathbf{3}$ & $\mathbf{2}$ & $\mathbf{1}$ \\
\hline 16. I like music. & & & \\
17. I love singing & & & \\
18. I have musical instruments which my & & & \\
$\quad$ parents bought for me. & & & \\
19. I like all types of music. & & \\
20. I always enjoy music classes & \\
21. Music is one of my best subjects in school & \\
22. I will read music in the University &
\end{tabular}




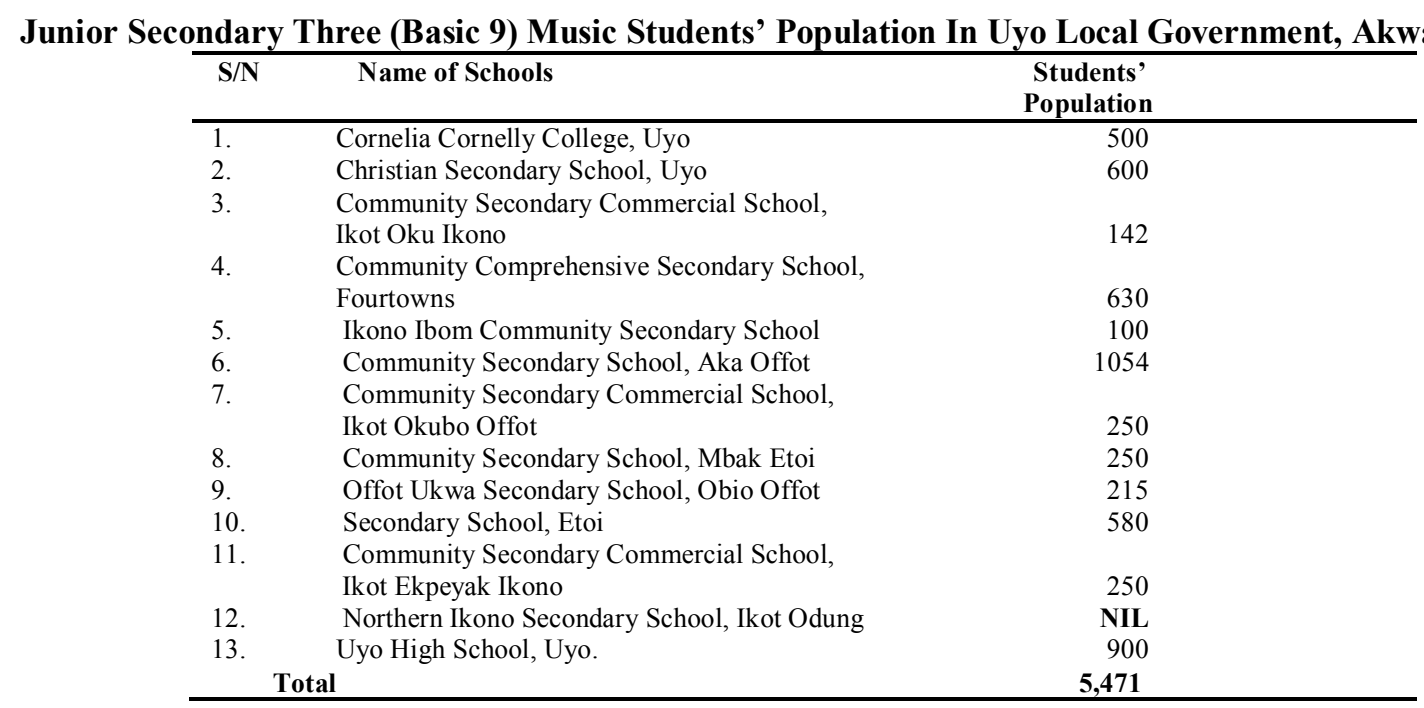

Grace E. Ekong is currently a lecturer in the Department of Music, University of Uyo, Akwa Ibom State, Nigeria. She had her academic musical training at the University of Cross River State, Uyo (Nigeria Certificate in Education); the University of Nigeria, Nsukka, Nigeria (Bachelor of Arts and Master of Arts); and finally at the Nnamdi Azikiwe University, Awka, Nigeria (Ph.D). Her area of specialization is Music Pedagogy and Performance. She teaches courses in music education, African music, research, history of Western music, performance (Western/African dance, Oboe, and voice). She is a singer, dancer, music pedagogue, researcher, choral music/dance adjudicator. She has taught at the primary, secondary, and tertiary levels of education in her country. Her hobbies include singing, games and sports, dancing, reading, meeting great minds for exchange of ideas. Her interest is in music pedagogy, research and practice in music education, African music studies, performance, and inter/intra musical culture exchange. She has several articles to her credit. 